University of Nebraska - Lincoln

DigitalCommons@University of Nebraska - Lincoln

$9-11-2020$

\title{
Comparing Profitability and Management Factors Across Operation Type: Independent vs. Contract Growing
}

Elliott James Dennis

University of Nebraska - Lincoln, elliott.dennis@unl.edu

Follow this and additional works at: https://digitalcommons.unl.edu/ageconfarmmgmt

Part of the Agribusiness Commons, Entrepreneurial and Small Business Operations Commons, Management Information Systems Commons, Meat Science Commons, Other Business Commons, and the Other Economics Commons

Dennis, Elliott James, "Comparing Profitability and Management Factors Across Operation Type: Independent vs. Contract Growing" (2020). Extension Farm and Ranch Management. 47. https://digitalcommons.unl.edu/ageconfarmmgmt/47

This News Article is brought to you for free and open access by the Agricultural Economics Department at DigitalCommons@University of Nebraska - Lincoln. It has been accepted for inclusion in Extension Farm and Ranch Management by an authorized administrator of DigitalCommons@University of Nebraska - Lincoln. 


\title{
Comparing Profitability and Management Factors Across Operation Type: Independent vs. Contract Growing
}

\author{
Dr. Elliott J. Dennis, Assistant Professor \& Livestock Extension Economist \\ Department of Agricultural Economics, University of Nebraska - Lincoln
}

There is strong local and national interest in adding hog barns to existing row crop operations. Declining on farm income over the past several years has accelerated this interest. Grain operations cite diversifying farm income, adding another family to the farm operation, and/or replacing commercial fertilizer expense as the primary reasons for adding a hog barn.

While there is industry demand to increase hog contract growing, these agreements can possess significant benefits and risks to producers. This is the third of a four-part series which will discuss some financial and legal implications of adding a hog barn to an existing grain operation. In part 1, I discussed how the type of hog operations in the US have changed over time, where hogs are raised in Nebraska, and how Nebraska compares to other states. The second part discussed the financial health of grain operations that added a hog barn compared to operations that did not adopt using various financial metrics. In this third part, I discuss and compare the profitability and management output between independent and contract growing operations.

\section{Independent vs. Contract Growing for Feeder-Finish and Wean-to-Finish Operations}

The previous section detailed how different financial measures for grain and grain + hog operations did not significantly differ. Three questions then remain. First, what part of the pork supply chain to enter. Second, what type of operation could be built. Third, how large should the operation be. To make these decisions, I focus on three key management metrics - estimated labor hours per unit, labor and management charge, and net return over labor and management. I then compare how these metrics differ between independent and contract growers and how stable these metrics are over time. My primary focus is on wean-to-finish and feeder-to-finish operations in the Northern Plains between 2008 and 2018. Comparisons are made using data collected from FINBIN and Nebraska Farm Business databases. Figure 1 displays these three key metrics and how they vary across years. The top three panels display the metrics for feeder-finish operations and the lower three panels display the metrics for wean-finish operations. The red line with circles represents independent growers and the green line with triangles represents contract growers. All results are displayed on a per head basis.

\section{Estimated Labor Hours Per Unit}

The number of hours required per head is substantially lower when hogs are grown under contract compare to independent growers. On average, independent finish barns spend 0.276 hours/head compared to 0.171 hours/head under contract. Wean-to-finish independent growers spend 0.281 hours/head compared to 0.152 hours/head under contract. The estimated number of hours per head is higher for independent producers but has been declining over time reflecting increased efficiencies in production. The number of hours per head for contract growers has stayed constant 
over time largely reflective of operations carrying out management plans given them to contractors. These findings are consistent across both feeder-finish and wean-finish operations.

\section{Labor and Management Charge}

The labor and management charges are relatively higher for independent producers than for contract growers. On average, independent finish barns charge \$3.91/head compared to \$2.49 under contract. This charge is highly variable through time and has recently started to decrease. For example, independent feeder-finish operations were paying $\$ 4.80 /$ head in 2008 and $\$ 2.75 /$ head in 2018. Wean-to-finish independent growers charge $\$ 2.83 /$ head compared to $\$ 2.48 /$ head under contract. Independent hog producer management charges increased sharply between 2008-2011 but have remained constant, on average, since 2012. Labor and management charges for hogs grown under contract has steadily risen over time for both feeder-finish and wean-finish operations. For example, contract feeder-finish operations were paying $\$ 1.80 /$ head in 2008 and $\$ 2.75 /$ head in 2018 . While these charges are rising, they have done so in a steady consistent manner. Overall, the labor and management charges for independent producers has tended to vary greatly from year to year.

\section{Net Return over Labor and Management}

Net returns over labor and management for contract growers are more stable over time compared to independent growers. The range $(\max -\min )$ of net returns for an independent feeder-finish operation is $\$ 40.80 /$ head compared to $\$ 2.61 /$ head under contract. The range for independent weanto-finish operation is $\$ 63.60 /$ head compared to $\$ 2.58 /$ head under contract. This large range occurs in part because an independent producer sells finished hogs at the market price thus capturing both market highs and lows. In contrast, most contracts pay a fee per head or pig space and then discount given actual production and health performance. Over time, the mean return per head for an independent feeder-finish operation is $-\$ 0.656$ and $\$ 0.813$ under contract. A similar story holds for independent and contract wean-to-finish operations: $-\$ 0.960$ and $\$ 0.524$, respectively. These net returns should be evaluated with caution since it is an average across producers with a variety of locations and sizes, does not take into account the value of manure, and represents the average of producer within a given year across a variety of contract arrangements and locations.

\section{Choosing the "Optimal" Contract Barn Size}

The previous results suggest that grain operations looking to add an additional steady form of income could do so by growing hogs under contract as either feeder-finish or wean-to-finish. The question then becomes how many pigs need to be handled each year in order to cover both the fixed and variable costs. To address this question, I show how the costs and returns change by operation size. I create four categories given their one-time head capacity: <1000, 1001-2500, 2501-5000, 5000+. Data was taken from FINBIN and Nebraska Farm Business for operations located in the Northern Plains from 2008 and 2018. Table 1 summarizes these findings.

On average, a wean-to-finish operation that grows hogs under contract would need to have a 25015000 one-time head capacity and turn the barn 2.45 times per year. There appears to be some substantial gains from increasing the barn size from 1001-2500 to 2501-5000 - nearly a $\$ 3.00$ difference in net returns over labor and management per pig space. This is compared to approximately a $\$ 0.60$ increase per pig space from 2501-5000 to 5000+. For hogs raised under contract for a feeder-finish operation, breakeven profits occur at 1001-2500 size operation turned 
2.24 times per year. There is not a significant premium for increasing the barn size from 10002500 to $2501-5000$ - about $\$ 1.60$ per pig space. This is compared to nearly a $\$ 5.00$ increase for an operation with 5000+ head capacity. In summary, grain operators adding a wean-to-finish operation could have positive net returns over labor and management per pig space with a 25015000 one-time capacity barn. For a feeder-finish operation, substantial gains are made once a onetime capacity is over 5000 head. Thus, the type and size of operation depends greatly on the amount of profit, and labor, an operation is willing and able to provide. 
Supporting Tables and Figures

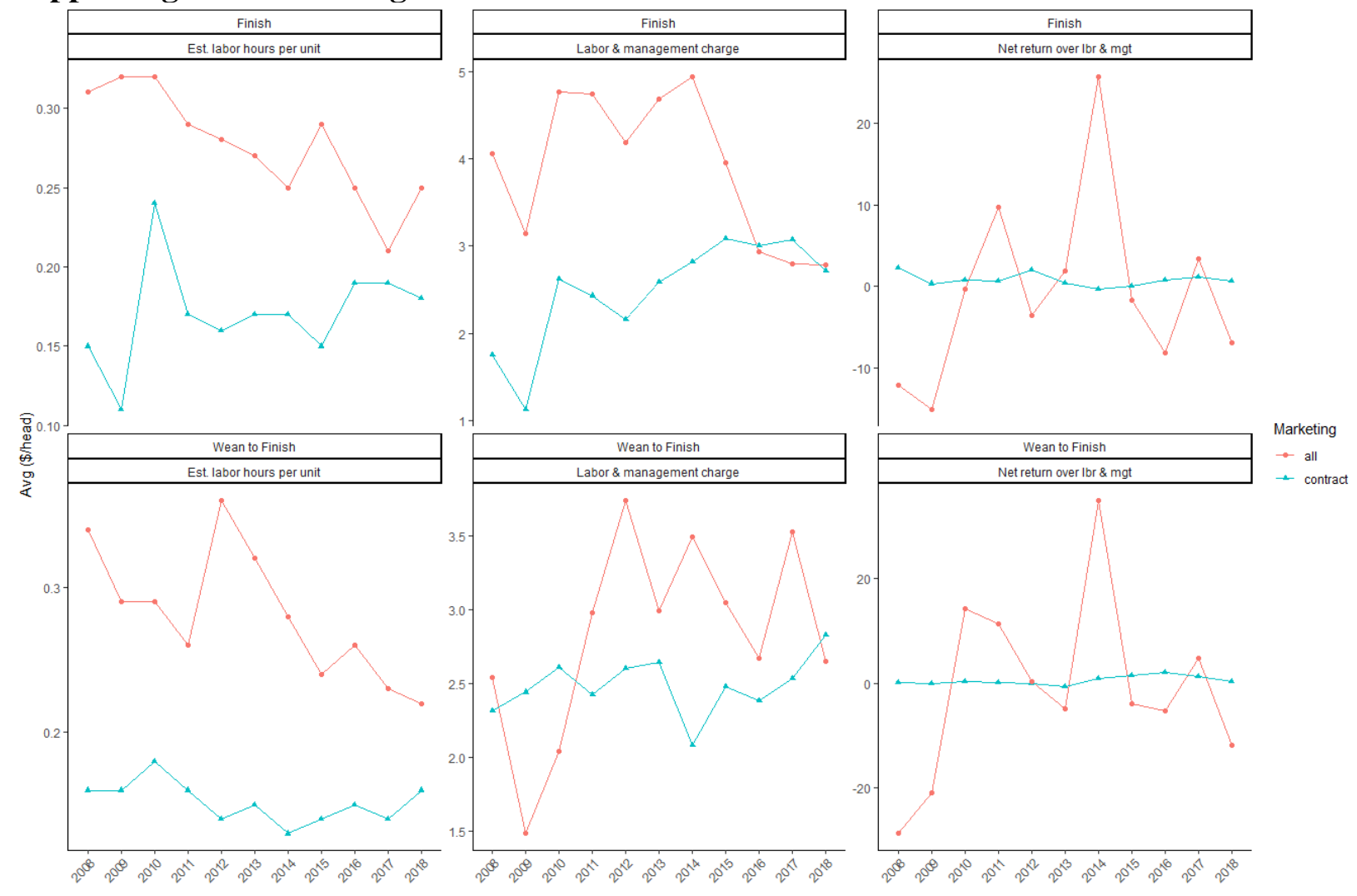

Figure 1. Key Farm Financials Across Different Type of Hog Operations and Contracts for Operations Located in the Northern Plains, 2008-2018

Notes: Lines represent the average producer within a given year for a given contract arrangement.

Source: FINBIN and Nebraska Farm Business databases (2008-2018)

Table 1. Performance Metrics by Type and Size of Hog Operations for Hogs Raised Under Contract in the Northern Plains, 2008-2018

\begin{tabular}{lcccc}
\hline & & \multicolumn{3}{c}{ Costs and Returns (per pig space) } \\
\cline { 3 - 5 } & $\begin{array}{c}\text { Pigs per } \\
\text { pig space } \\
\text { per year }\end{array}$ & $\begin{array}{c}\text { Return over } \\
\text { direct expense }\end{array}$ & $\begin{array}{c}\text { Total direct \& } \\
\text { overhead } \\
\text { expense per unit }\end{array}$ & $\begin{array}{c}\text { Net return over labor } \\
\text { \& management }\end{array}$ \\
\hline Wean to Finish & & & & \\
$<1000$ & 2.47 & 22.88 & 27.90 & -0.73 \\
1001-2500 & 2.26 & 25.46 & 32.31 & -1.54 \\
2501-5000 & 2.45 & 28.91 & 31.43 & 2.23 \\
5000+ & 2.32 & 26.66 & 28.98 & 2.86 \\
Feeder to Finish & & & & \\
$<1000$ & 2.62 & 23.22 & 30.28 & -2.87 \\
$1001-2500$ & 2.24 & 30.17 & 33.06 & 0.05 \\
$2501-5000$ & 2.33 & 24.57 & 29.64 & 1.63 \\
5000+ & 2.62 & 27.35 & 27.61 & 6.52 \\
\hline
\end{tabular}

Notes: Costs and Returns on measured on a per pig space basis.

Source: FINBIN and Nebraska Farm Business databases (2008-2018) 